\title{
Raising Pan Americans: Early Women Activists of Hemispheric Cooperation, 1916-1944
}

Dina Berger

Loyola University Chicago, dberge2@luc.edu

Follow this and additional works at: https://ecommons.luc.edu/history_facpubs

Part of the History Commons

\section{Recommended Citation}

Dina Berger. "Raising Pan Americans: Early Women Activists of Hemispheric Cooperation, 1916-1944." Journal of Women's History 27, no. 1 (2015): 38-61.

This Article is brought to you for free and open access by the Faculty Publications and Other Works by Department at Loyola eCommons. It has been accepted for inclusion in History: Faculty Publications and Other Works by an authorized administrator of Loyola eCommons. For more information, please contact ecommons@luc.edu.

\section{(c) (i) $\Theta$}

This work is licensed under a Creative Commons Attribution-Noncommercial-No Derivative Works 3.0 License. (c) Journal of Women's History, 2015. 


\title{
RAISING PAN AMERICANS:
}

\author{
Early Women Activists of Hemispheric Cooperation, \\ 1916-1944
}

\section{Dina Berger}

This article examines the early years of the Pan American Round Table (PART), a women's group founded in Texas in 1916 that internationalized to Latin America by 1928. While men built bridges and highways that connected the United States and Latin America, women of the PART built metaphorical ones of friendship and understanding. They acted as agents of "soft" diplomacy reshaping Pan Americanism, a U.S. foreign policy goal intended to foster commercial and political ties and to spread democracy in Latin America. Their activist work on behalf of Pan Americanism became a vehicle for personal and community enrichment: through education of self and public, they believed they could change attitudes toward Latin America and its people, yielding a common ground of mutual respect as their motto "liking comes from knowing" suggested. The PART is thus a model study for the interplay of gender, diplomacy, and foreign relations in the twentieth century.

$\mathrm{O}$ April 14, 1935, women of the Pan American Round Table (PART) stood on the international bridge where the cities of Laredo, Texas and Nuevo Laredo, Tamaulipas met to dedicate a bronze marker to the women of the Americas. Hortencia Elías Calles de Torreblanca, wife of the Mexican minister of foreign affairs and daughter of former president Plutarco Calles, unveiled a round marker embossed with entwined flags of the Pan American Union (PAU) set against the backdrop of North and South America; below it read "One for All, All for One." Members of the PART from San Antonio, Brownsville, and Laredo orchestrated the entire affair, attended by hundreds, including governors and their wives from Texas, Tamaulipas, and Coahuila, and a cast of U.S. and Mexican consular and border officials. A luncheon followed at the Hamilton Hotel where men and women of Mexico and Texas mingled. No ordinary dedication ceremony, the event took place on the official calendar date of Pan American Day and just ahead of the official opening of the first major highway linking Texas to Mexico City. In one of the many speeches that day, the head of the Mexican Division in the U.S. State Department commented that "the erection of the marker fulfills a prophetic rather than a commemorative purpose," representing a 
new era of hemispheric cooperation. He noted too that border communities had long been places of "social and business intercourse" where "Mexicans and Americans mingle freely" and where women of the PART had "already done so much to foster friendly relations." ${ }^{1}$ The PART was, indeed, the first women's group in the United States dedicated to rearing Pan Americans and to promoting the larger cause of hemispheric understanding.

This ceremony speaks volumes to the kind of work the PART performed on behalf of inter-American solidarity. While men built bridges and highways that connected the United States and Latin America, women of the PART built metaphorical ones of friendship. They acted as civic diplomats advancing Pan Americanism, a U.S. foreign policy ideal of hemispheric cooperation intended to foster commercial, political, and eventually cultural ties throughout the region, and a rhetorical tool that became central to U.S.Latin American relations by the 1930s and during the Cold War. The group's Pan American activism became a vehicle for personal and community improvement: members saw themselves fulfilling a noble service-a kind of civic and spiritual duty-to nation and hemisphere through education of self and the public about Latin America. They provided services to their immediate communities across Texas and to an imagined hemispheric one, whether through the creation of a Pan American library at the Gunter Hotel or the donation of books to help build one in Mexico City. Encouraged by the objectives of the PAU under John Barrett (1907-19) and his successor Dr. Leo Rowe (1920-46), the PART worked to expose themselves and their communities to their southern neighbors. Their group motto, "liking comes from knowing," suggests how members saw knowledge about the other as the key to hemispheric cooperation. How and, to some extent, why women of the PART carried out a mission to raise Pan Americans is the subject of this article.

The PART drew inspiration from Barrett's notion of "Practical Pan Americanism," a concept that encouraged every American to take responsibility for practicing good will toward the people and governments of Latin America. In speeches across the country and in print media, Barrett went so far as to draw a clear picture of an imagined hemispheric family, imploring all Americans-government officials, journalists, teachers, and ordinary citizens - to treat Latin Americans "as one man would towards another, as one family [would] towards another family, as one community [would] towards another community." ${ }^{2}$ Building this Pan American community, he argued, "will lead to lasting peace, secure friendship, and great commercial exchange between the United States and her" sister republics. ${ }^{3}$ Barrett's suggestion that everyone had a role to play in promoting this ideal formed the backdrop of a Pan American civic movement that was especially popular and uniquely inclusive. In his cross-country tours, Barrett spoke 
to businessmen, journalists, women's clubs, youth groups, and university students. With no funding and little guidance from the PAU, the gradual growth of Pan American civic groups over the course of the twentieth century, from a handful in 1930 to over 300 groups by the 1950s, suggests the grassroots nature of Pan Americanism. The only evidence of any concerted effort to provide guidance on how to form a Pan American group can be found during World War II when the Office of the Coordinator of InterAmerican Affairs published a pamphlet with suggestions drawn directly from the kinds of programs the PART had been carrying out since 1916. ${ }^{4}$

The PART also emerged in response to local conditions, albeit ones influenced by national actors. Mrs. Florence Terry Griswold, its founder, was undoubtedly shaped by her upbringing near the U.S.-Mexico border. Her life there was a place where Griswold "learned to esteem and value [the Mexicans'] qualities of loyalty and devotion." ${ }^{5}$ Living on the border in Eagle Pass as a wife, mother, and eventual widow, Griswold's granddaughter describes how moved she was to see mothers and children fleeing the violence of the Mexican Revolution. ${ }^{6}$ Her empathy for the Mexican experience, coupled with a unique borderland identity, prompted her to call a meeting of twenty-two likeminded women in San Antonio to form the Pan American Round Table in 1916. It may be worth noting that the women met at a crucial moment in U.S.-Mexican history. Tensions between governments had escalated during Mexico's revolution, resulting in the U.S. occupation of Veracruz in 1914. The year these women formed the PART, Pancho Villa had wreaked havoc in Columbus, New Mexico, and President Woodrow Wilson responded by sending General Pershing and his troops to capture the Villistas. Meanwhile, in Washington, D.C., Barrett publicly promoted arbitration, not intervention, through the Pan American Union. He wrote an essay, "Mexico: A Land of Potentiality," in which he dispelled common myths about Mexicans as anti-American and incompetent, advocating, instead, cooperation as the key to peace and prosperity in Mexico. ${ }^{7}$ The convergence of borderland unrest with a national call to hemispheric comity or, worse, war, produced an opportune moment for local women like Griswold to harness their energy toward a Pan American cause, something reflected in the organization's reach as it spread first throughout south Texas, to the border cities of Laredo, El Paso, Brownsville, and McAllen in the 1920s-1930s. The group later formed in the Dallas-Ft. Worth area by the 1940s. ${ }^{8}$ Thus, proximity to the Mexican border and exposure to Mexican culture and peoples likely motivated women at the time to act on behalf of Pan Americanism. ${ }^{9}$

Pan American civic groups like the PART provide a window into the interplay of civic activism, gender, and foreign relations in the twentieth century. These groups, organized around common age, profession, sex, and 
social status, were a reflection of society and broader club culture in the United States. Where members would have intersected were in advisory roles. A member of the affluent men's Pan American Society, for example, might sit on the advisory board of the all-women's Pan American League. While the PART flourished with the support of men at home and in government, women members saw their Pan American work as an extension of women's work, much in the way the historian Paige Meltzer suggests for the clubwomen she examines. ${ }^{10}$ She shows how clubwomen's role as mothers and homemakers, whose job it was to take care of their immediate family and the larger body politic, legitimized their activist work carried out before and after World War II. This maternalism became particularly important in the postwar era as the conservative General Federation of Women's Clubs encouraged clubwomen to engage in a new culture of domesticity that disseminated democratic values of civic-mindedness, consumption, and negotiation. ${ }^{11}$ Women of the PART similarly carried out their mission in normative ways, through self and civic education. Griswold openly voiced her disapproval of women internationalists. In 1930, she declined an invitation from the Women's International League for Peace and Freedom (WILPF) to attend an inter-American conference. In her letter to WILPF member Kathleen Jennison Lowrie, she explained that the PART believed politics to be "petty" and admonished League members for not dutifully using their husband's names. She concluded by pointedly stating that women of the PART were apolitical and saw their involvement as strictly social and cultural. ${ }^{12}$

Yet the kind of civic work performed by members of the PART reveals a more complex picture. On the one hand, members performed Pan Americanism in feminine ways. They hosted monthly luncheons where diplomats and university professors lectured on Latin America and where they performed Latin American poetry or music. They also organized Pan American Day celebrations and fundraising events to create Pan American libraries and to provide scholarships to young Latin American women hoping to study at Texas universities. On the other hand, PART members successfully navigated the landscape of international politics, corresponding with Rowe at the PAU and other government men of import, never missing an opportunity to host a visiting dignitary or academic. The PART struck a balance between civic-mindedness (typical of a woman's club in this era) and politics. Rather than couch their activism in overtly maternalist language, Griswold guided the organization away from the banal woman's club and toward, in her view, a club with a highly noble mission of hemispheric community-building. In fact, her choice to use the term round table not club speaks to the group's commitment to friendship, negotiation, and compromise-ideals no different from the postwar objectives of the General Federation of Women's Clubs. ${ }^{13}$ 
The ways in which the PART approached civic Pan Americanism may explain their gradual appeal to women in Latin America where today there are over 200 clubs and 6,000 members. With the exception of a club in Mexico City founded in 1928 by women of the American Colony, most Latin American round tables, called Mesas Rendondas Panamericanas (MRP), were incorporated in the 1940s and thereafter. The earliest groups can be found in the capital cities of Cuba, Honduras, Argentina, Costa Rica, Nicaragua, and in northern Mexico, often established as a result of a personal connection with Texas. For example, Dr. Angela Acuña, who was born in Costa Rica but lived in Dallas, used her connections to found the MRPs in San José, Costa Rica, and Tegucigalpa, Honduras, while Texas-born Collin McCown de Garza, who married a Mexican, founded the Monterrey club in 1944. Meanwhile, Mexico has been central to the proliferation of Pan Americanism, boasting seventy-seven tables as of 2009 located in three zones across the country, from tourist peripheries like Cancun and Oaxaca to mining communities like Fresnillo. While a study of Latin American clubs is beyond the scope of this article, it is worth mentioning that proximity to the United States and zones of contact with Americans may explain the mapping of the transnational round table movement.

Given the PART's objective, its early history was rife with contradictions and a few controversies. The most prominent of these have some broader implications for our understanding of Pan Americanism and women's articulation of it, namely that the well-meaning work to build a hemispheric community was not immune from the trappings of local political cultures or long-held beliefs about Latin American inferiority. Furthermore, we can see that Pan Americanism was a fundamentally U.S.-driven, U.S.-defined aspiration. For example, early members of PART in Texas and Mexico City had the foresight to "get to know" their Latin American sisters but they were not necessarily progressive. At PART celebrations members dressed up in traditional "costumes" that fetishized Latin American culture, while Griswold believed the founding American members of PART-Mexico City should "show the Mexican women how to grow"; in other words, Americans were in the superior position to teach Mexicans how to be good Pan Americans. ${ }^{14}$ Likewise, as I will address later, American expatriates who founded the first Mexico City Pan American Round Table in 1928 initially excluded Mexican women from its membership. Pan Americanism-the ideal and the civic movement-was thus limited by the visionaries themselves.

A study of the PART suggests new ways of thinking about the quotidian and gendered enactments of foreign relations within the broader transnational currents of women's activism and U.S.-Latin American relations in the twentieth century. New diplomatic scholars have illuminated the myriad forms of public diplomacy, a form of "soft" power, to show how 
people-from entertainers to philanthropists-play a role in mediating foreign relations through the dissemination of ideas, cultural practices, and values. Works on industrialists like John D. Rockefeller and Henry Ford, peace activists and internationalists, university professors and students, musicians, and tourists have pushed our understanding of diplomacy beyond official state actors and government programs to the more ordinary and oft-overlooked forms of international politics. ${ }^{15}$ Civic organizations like the PART should be understood as key agents of diplomacy, effecting change in public opinion, building bridges of friendship, and spreading values of hemispheric citizenship.

This study also enriches our understanding of Pan Americanism itself. Scholars have written extensively about hemispheric relations, focusing on the economic and political impact that U.S. capital, financial institutions, and even cultural practices have had on the region; others examine key presidential administrations, such as Wilson's and Franklin Roosevelt's, where we find major shifts in U.S.-Latin American policy. ${ }^{16}$ Within the scholarship on Pan America as an ideal, the greatest contributions are works that focus on the Pan American Union, namely its role in arbitrating hemispheric conflicts that ended wars or helped to avoid them and in galvanizing support for a particular position. Works also address the many important semi-official Pan American conferences on the sciences, public health, feminist and maternal welfare, commerce, medicine, child rights, and education. These conferences provided a forum for "Americans" writ large to advocate for constitutional reforms and welfare state programs. ${ }^{17}$ Women's historians in particular have shown how Pan American conferences served as vehicles for policy advancement. The historians Donna Guy and Lynn Stoner illustrate how child rights advocates, maternalist feminists, and suffragists used Pan American congresses to press for legal and social welfare reform, suggesting ways that women used Pan Americanism to evoke change. ${ }^{18}$ Little is known, however, about Pan American activists who formed membership in a hemisphere-wide club movement that began in the early twentieth century thanks in large part to Barrett's work. This study seeks to understand how women of the PART appropriated Pan Americanism when cross-cultural friendship, not reform, was the goal.

\section{Spreading Pan Americanism from Texas}

A political concept of unity initially conceived by Simon Bolívar in the 1820s, Pan Americanism came to define a U.S. policy of commercial and political expansionism by the late nineteenth century. ${ }^{19}$ Advocated by former Secretary of State James Blaine as a vehicle for building peace in a contentious hemisphere fraught with territorial conflicts, it gained popular- 
ity in the U.S. Congress as a way to create a sphere of commercial influence south of the border. ${ }^{20}$ By the time the first hemispheric meeting was held in Washington in 1889 under Blaine's tutelage, delegates from twenty-one nations met to create new trade ties and markets. ${ }^{21}$ What came out of that first meeting was a fledgling agreement to form the International Bureau of American Republics. While commercial interests drove the first few official hemispheric conferences, this changed in 1906 when Barrett was named director of the Bureau, which was renamed the Pan American Union in 1910 . With a $\$ 750,000$ donation by Andrew Carnegie and a $\$ 250,000$ congressional appropriation, an architectural gem was constructed to house the Pan American Union located on the main thoroughfare in Washington, D.C. on 17th Street Northwest and Constitution Avenue. The organization, though an unofficial one, was set at the center of Washington politics as a kind of statement about the larger goals of the union, namely that it would bring peace and, especially, prosperity to the western hemisphere just as European aggression grew.

Under Barrett's leadership, the Pan American Union became the clearinghouse for information about Latin America, especially commercial statistics. Barrett became the single most important advocate for hemispheric comity, a kind of mover and shaker for Pan Americanism. He kept a busy work schedule balancing luncheons and banquets with hundreds of speaking engagements and an outstanding publication record. Barrett helped to shift attention away from commercial relations and toward an ideal of Pan Americanism and the imagined hemispheric community. He advocated mutual respect through understanding. He was the first to criticize U.S. foreign policy in Latin America and often clashed with members of the State Department and even presidents when he saw the U.S. government infringe on Pan Americanism. Barrett advocated for what he called the "Pan Americanization" of the Monroe Doctrine. This meant true hemispheric cooperation and a real mental shift in U.S. political thought, whereby Latin American governments would stand by the United States in the event of a threat, just as the United States would stand by Latin America. In short, Barrett promoted an ideal of equality among all peoples and governments in the western hemisphere, ideas that resonated with important officials, namely President Wilson, who drew on Barrett's definition of Pan Americanism for his famous 1913 Mobile Address. ${ }^{22}$

After twenty-one years as professor of law and government at the University of Pennsylvania, Rowe took over the PAU as Pan Americanism had begun to gain currency as an official, state-sanctioned diplomatic tool. ${ }^{23}$ The Union's vision would eventually pave the way for Roosevelt's Good Neighbor Policy of the 1930s, a policy of political nonintervention and investment in building cultural and social ties. Rowe's overall approach to 
Latin America was similar to Barrett's in that he argued for multilateralism, not unilateralism, as the key to regional development and the growth of strong democracies and economies. ${ }^{24}$ Like Barrett, his approach was neither altruistic nor devoid of longstanding beliefs about U.S. exceptionalism, understanding the U.S. mission in Latin America as one that would marshal the region toward modernization. Modernization would come about not just through political cooperation or commercial trade, but through a new component: cultural and intellectual exchange. ${ }^{25}$ The kinds of cultural relations introduced by Rowe reached their apex with the founding of exchange programs like the Fulbright Program, sponsored by the State Department. ${ }^{26}$ Exposing people of the Americas to one another would thus contribute to the broader mission of hemispheric unity and friendship. ${ }^{27}$ Over the course of Barrett's and Rowe's combined thirty-eight years of leadership at the PAU, Pan Americanism captured the attention of politicians, philanthropists, and ordinary Americans around the aspiration of a hemispheric community.

At the helm of the PART until her passing in the 1940s, Griswold fervently believed in both the prospect of Pan Americanism and women's natural role in it. She saw similarities between the founding fathers of the Americas-San Martín, Bolívar, Hidalgo, and George Washington-and envisioned a unified destiny for the two continents, the creation of which women would play a central role. Griswold contended that if women became friends, men on both sides of the border could no longer misunderstand each other because, without commercial, financial, or political stakes, women "can meet with mutual sympathy and friendship." 28 Although its mission was supposedly apolitical, the very nature of PART's work as good neighbors embodied the spirit of politics and diplomacy. PART's work was an extension of women's work and an exercise in self-study, civic education, and philanthropy. The twenty-two founding members in San Antonio, for example, set a precedent whereby each Table member studied one country in Latin America and presented their findings at monthly luncheons or teas. Over time, luncheons included honorary guest speakers from the government, diplomatic corps, and university community who lectured on some aspect of Latin American politics, economics, or culture. The San Antonio Table, for example, hosted a talk by Mexican Minister of Foreign Relations, Aaron Sáenz, when he was en route to Cuba in 1925. In 1933, the El Paso Table invited a prominent judge from Ciudad Juárez who, they wrote in a report, "made a plea that the women of [Mexico and the United States] could forever be the dovelike messengers for which they were intended, and could forever mother the magnanimous situation of peace and friendliness." ${ }^{29}$ And, in 1944, Mexican Consul Luis Pérez Abreu lectured on preColumbian civilizations at the home of a Dallas Table member. ${ }^{30}$ It was not uncommon that luncheons or teas also included Latin American fare and a 
cultural performance by a Table member who either sang in Spanish, played a piano piece by a Latin American composer, or recited Latin American poetry. Learning Spanish was an important component of self-study for PART members. Most Tables organized Spanish-language courses for members and, in some cases, the broader community. By the mid-1940s, some Tables even incorporated a compulsory, Spanish-only language policy when dessert was served. For example, the McAllen Table-where half its members were Mexican-American-passed a rule to punish those caught speaking English during dessert with a ten-cent fine. ${ }^{31}$ The PART also helped draft a resolution to introduce Spanish-language curriculum in Texas public schools, which eventually passed the state senate in $1941 .^{32}$

The PART's work focused on civic education. Members organized projects to build Pan American libraries in the United States and in Latin America. In 1942, members in Texas and Mexico City played a major role in founding and stocking the shelves of the famous Benjamin Franklin Library in the U.S. Embassy in Mexico City. Closer to home they established local Pan American reading rooms, like those found in San Antonio at the Gunter and St. Anthony Hotels, or donated books about Latin America to public libraries, including a Pan American library in San Antonio's historic La Villita near the Riverwalk. Likewise, in the 1940s, the Silver City, New Mexico Table, whose members were mostly educators, established a library for Mexican-American children at a local community center. ${ }^{33}$ They also designed cultural programming for the broader community. Members wrote and produced radio programs that aired over local Texas stations; "The Young Ambassador," for example, produced by a Dallas Table member in 1942, aired in Dallas and Houston and was replayed for students in public schools. ${ }^{34}$ Written by Maria de Haro, this child-friendly series centered on the life of a young American boy who lived in Mexico City with his aunt and uncle while his parents toured South America. Through dialogue between Jackie and his new Mexican friends, audiences learned about Mexican culture and history. ${ }^{35}$ PART members also played host to the famous Mexican Arts Exhibit in 1930, which opened at the Metropolitan Museum of Art in New York City and featured famous Mexican contemporary artists like Diego Rivera, José Clemente Orozco, and Carlos Mérida (to name only a few), as well as fine art from the colonial and national periods. San Antonio members made all the hometown arrangements, which included booking the Witte Memorial Museum and organizing the opening reception. Table members impressed other "civic-minded folks" from a variety of men's and women's clubs-the Catholic Women's Association, Council of Jewish Women, Rotarians, Kiwanis, and Choral Club — to act as docents and hosts for the duration of the exhibit from August 12 to September 9. Their efforts were a huge success: an estimated 50,000 visitors (1,500 per day) enjoyed 
the museum exhibit, exposing thousands to a slice of Mexican history and culture. ${ }^{36}$ Likewise, Tables throughout the Southwest held local essay contests at middle and high schools whereby students submitted essays on subjects related to Pan Americanism for cash prizes. The Las Cruces, New Mexico Table, for example, gave war bonds to winners in the early 1940s. ${ }^{37}$

PART members often performed and spread Pan Americanism through public displays and commemoration. The most common of these was the yearly celebration of Pan American Day on April 14. Members organized community ceremonies and invitation-only banquets. In 1936, the Brownsville Table organized a Pan American Day at the home of one its members. An estimated 150 people were greeted by charros (Mexican cowboys). Guests sat at one of sixteen tables organized by a PART member to represent a different Latin American country and its respective cuisine: rice, enchiladas, and imported pulque at the Mexico table; barbequed beef and pork at the Argentina/Uruguay table; and mate at the Brazil table. Meanwhile, PART members dressed in traditional Latin American costumes. ${ }^{38}$ In 1951, the McAllen Table hosted a coffee for 300 people at the fancy Casa de Palmas Hotel where children from Reynosa (across the border) performed traditional Mexican songs and dances. ${ }^{39}$

On occasion, the PART spearheaded efforts to memorialize their mission on plaques in public spaces. The first of these was the bronze marker on the international bridge described earlier. Griswold spearheaded the project. She spent over a year soliciting approval for the marker at various binational agencies, raising funds and designing it, and organizing the ceremony to dedicate it. ${ }^{40}$ Over a decade later, in 1947, San Antonio dedicated a round bronze marker that weighed over 250 pounds in the city's downtown Municipal Auditorium. Emblazoned on the plaque was PART's emblem featuring the map of Texas surrounded by flags from twenty-one member nations. At the top read PART's motto: "WHEN WOMEN UNDERSTAND EACH OTHER, MEN CAN NO LONGER MISUNDERSTAND." Like the 1935 ceremony, this one also included the Texas governor and his wife, a personal representative of the Mexican president, and countless consular officials from across Latin America. Although symbolic at best, these public displays of Pan Americanism bolstered the profile of both the Round Table movement and hemispheric unity, which was increasingly vital to the U.S. government by the mid-1930s as war loomed in Europe and threatened stability in the Americas.

Outreach work was also a component of PART's mission, especially its scholarship programs. While the group awards over one hundred educational scholarships to Latina students in Texas today, the program in its early years provided a modest number of scholarships to expose young Latin American women to American life. ${ }^{41}$ Complementing intellectual 
exchange programs like the Fulbright, the PART brought young women to the United States in the mid-1940s. The Austin Table was one of the first to do so, securing one hundred scholarships from the Texas State Legislature in 1941; in 1945 they guaranteed funds through the Institute of International Education and the University of Texas (UT) to pay the tuition of Latin American students studying at the UT-Austin, while giving eight of their own scholarships in the amount of fifty dollars each to offset costs. ${ }^{42}$ Other Tables followed: the Dallas Table raised $\$ 500$ to fund a scholarship program for graduate students of Latin American descent at Southern Methodist University and funded the training of a Guatemalan nursing student at Baylor University while the San Antonio Table raised money to offer a scholarship at Our Lady of the Lake College to a young Honduran woman who was poor and in the top eight percent of her class. ${ }^{43}$

PART members were also hosts to Latin American visitors, namely educators, students, and diplomats. In university towns, Tables held teas in honor of Latin American students attending institutions or they invited students to speak about their native country at monthly luncheons; others filled linen chests for newly arrived Latin American students. ${ }^{4}$ The Houston Table opened a formal Hospitality Center to welcome visitors and to teach Spanish courses. There they reportedly offered Latin Americans access to Spanish-language newspapers, "books on Latin America, travel information, writing materials and even phone service." ${ }^{45}$ Some members went so far as to act as surrogate parents for many of the visiting Latin American students. In 1953, two San Antonio Table members and their husbands picked up a Honduran scholarship student (and her family) at the airport, housed her, drove her to college, and even helped her pick out classes. In their report, the members bent over backwards to prepare her for the school year, outfitting her with new clothes, shoes, socks, and a hat, and providing her with a monthly stipend for incidentals. ${ }^{46}$ Meanwhile, the Houston Table, whose director was the wife of Rice University's provost, set up an International Room in 1955 where volunteers entertained Latin American visitors. ${ }^{47}$

Through their missionary work, the PART sought to heighten awareness about the culture and peoples of Latin America, acting as agents of a larger political mission aimed at building solidarity not just between nation-states but between citizens. They acted as agents in ways considered appropriate for women and pleasing to men. One Mexican judge echoed this at a luncheon in 1933, praising the PART for acting as doves and mothers who forwarded world peace by rearing good citizens. With an international view that obfuscated more immediate issues at home-namely, their failure to take a stand against discrimination against Mexican Americans in Texas-members worked against anti-American sentiment in Latin America. As one Table member states, with our activities, "we could offset the pro- 
paganda and the bad manners so often displayed by the tourist class who went to Mexico in the early days." ${ }^{48}$ By putting their best foot forward and generously funding educational exchanges, or by inviting Latin American students to dine in their homes, women of the PART represented the good neighbor par excellence and dispelled, in their small way, Latin American perceptions of the U.S. leviathan.

To work against anti-Americanism, the PART sought to spread the gospel of Pan Americanism in what became a hemisphere-wide Round Table movement. A success today, the earliest efforts beyond Texas borders were less so, which disappointed Griswold. ${ }^{49}$ The Mexico City controversy, in particular, suggests the limits of the Pan American mission and the fault lines of the Pan American ideal itself. It was a catch-all idea open to interpretation and taken up as a cause to meet personal, national, and even international objectives. Despite living in Mexico, early members of PART-Mexico City were almost entirely Americans who joined the movement not necessarily to forge friendships with Mexican women around them but, more likely, to socialize with other women of the American Colony and to learn about the unfamiliar region in which they lived. As Pan Americanism gained popularity and purpose during World War II, PART-Mexico City began outreach work while new Tables cropped up in northern Mexico cities like Monterrey and Reynosa where one was more likely to find Americans more integrated into local culture and, as such, more likely to speak Spanish and to form friendships with Mexican women. Because Pan Americanism was an aspiration, positionality mattered in the case of Mexico (the north versus the center) just as it did in Texas (El Paso versus Dallas). ${ }^{50}$ It shaped the Pan American mission and the form that mission took.

\section{Interpreting Pan Americanism from Mexico City}

It is somewhat peculiar that Mexico City instead of a nearby northern city became the location for the first PART-Mexico club. Given the strong American colony there by the early 1920s, Mexico City seemed an ideal place to promote friendship between Americans and Mexicans but it was also peculiar because scholars have shown that the American Colony there was exclusive, even if only middle class, made up of engineers, insurance agents, scientists, and managers in the airline, oil, and manufacturing industries who resided with their families apart from the real Mexico in which they lived. ${ }^{51}$ Graduate student in history Birgit Nielson describes the American Colony as an island, "isolated and cohesive," whose members "refused to be assimilated into Mexican culture." ${ }^{52}$ Because their education and employment secured them a place of privilege in Mexico City, Americans never needed to assimilate to Mexican society. Their social and cultural capital 
meant that they need not live in an enclave community but lived dispersed throughout Mexico City. Privileged and scattered, the American Colony was a lifestyle rather than a cohesive, homogenous community. ${ }^{53}$ Given the cosmopolitan nature of Mexico City and the general admiration of American culture, members of the colony neither learned nor spoke Spanish. They built a "colony lifestyle" that sustained American customs and values while also staying connected to other Americans through institutions like the American School, social clubs like the Mexico City Country Club and the American Legion, philanthropic associations like the American Benevolent Society, and churches like the Union Evangelical Church. ${ }^{54}$ Some of these institutions were theoretically open to the broader chilango (residents of Mexico City) and foreign communities. Enrollment at the American School by 1941, for example, was half Mexican and the Mexico City Country Club was open to all as long as prospective members could purchase stock in the club and pass the rigorous application process. This colony lifestyle was maintained on the whole through membership in social and civic clubs, which often doubled as sites of exclusion and segregation. The American Club, Legion, and Benevolent Society excluded non-Americans while the Union Evangelical Church served a largely American and British congregate given that most Mexicans at the time were Catholic.

If exceptionalism characterized the American Colony of Mexico City, it is odd that these women prompted the founding of a group that promoted the cause of solidarity between citizens of the Americas. PART records indicate that the first Mexican table was founded by "a former member of the San Antonio branch [who] moved to the City of Mexico." ${ }^{55}$ Some of the founding members in Mexico City came into contact with the Round Table idea through friends and family in Texas or caught wind of it at some point in their travels between Mexico and the United States, which often entailed stops in Texas. ${ }^{56}$ The instructive controversy over membership in PART-Mexico City nevertheless shows an early disconnect between the club's fundamental mission to "foster mutual understanding and friendship with peoples of the Americas" and how American women in Mexico City imagined their place in the Pan American movement, especially from their unique position as colony members.

In 1928, two groups vied to establish an official PART club. On one side was a group of well-meaning Mexican women led by Luz Cosío de López (whose background is so far inconclusive) and included Srta. Maria Canales, Sra. Santibañez, and Margarita de Soto Hay. The opposing group was spearheaded by Mrs. J. Walter Christie, the wife of an insurance agent and member of the Union Evangelical Church; Mrs. Maurice Hugo, wife of a manager at Guest Aerovías de México; and Mrs. Walter E. Purple, wife of the operating manager of a medical supply company-all colony women 
who were already part of a History Club that began to study Pan American affairs. One can be sure that women in both groups were important enough (well-heeled, English-speaking, prominent members of the colony and of Mexican society) to catch wind of this Pan American movement during their travels through Texas.

To be clear, no competition actually existed; the Mexican women assumed they could join the proposed club. But the women of the American Colony openly refused to let them join a club despite its purpose of fostering good will. Correspondence reveals that the American women were not willing to hold meetings in Spanish and were of the mind that the PART was to be an American-based club, choosing to hold meetings at the exclusive University Club and later at the American Club. ${ }^{57}$ Women of the American Colony did not exclude Mexican members altogether; rather, they quite strategically invited Sra. Ramón Beteta, wife of the soon-to-be undersecretary of foreign relations under Cárdenas, to join. The American women refused to budge while the Mexican women were clearly (and rightfully) offended by their exclusion; both wanted to begin a Pan American Round Table, if not together then separately. From San Antonio, Griswold tried but failed to help them reach an agreement. In letters to both parties, she was polite, refusing to condemn the American women outright for their lack of mission. Instead, she encouraged the Mexican group to continue their Pan American work but to do so under a different name. In response, they established an organization called the Union Feminina Ibero-Americana (Ibero-American Feminist Union or UFIA) to reflect their own brand of Pan Hispanismo, which emphasized the historical link between Latin America and Spain. By 1936, the PART-Mexico City and the UFIA buried the hatchet and began to attend each other's events, although the UFIA declined Griswold's later offer to join PART; by then, they had begun to establish branches throughout Latin America and had passed a resolution never to formally join the group. ${ }^{58}$ Of the first twenty-two PART members in Mexico City, only three were Mexican.

When Mexico City members abruptly resigned from the PART in 1940 over a lack of voting rights in decisions emanating from Texas, Griswold wrote that the women of Mexico City "have always failed to understand that a Roundtable in the Republic of Mexico should be composed of Mexican women, and the Americans to serve as associate members of the group; in other words, they should have been willing to show the Mexican women how to grow." ${ }^{59}$ One can imagine the difficulty in showing Mexican women how to be good Pan Americans when colony women did not play that role themselves. Expressing her disappointment about their resignation to a colleague, Griswold wrote: "In my years of experience I have found those who criticize contribute little to an organization. Anyone can tear down, but 
it requires intelligence and broad-mindedness to build. Envy and Jealousy are terrible diseases. You see everyone does not have an understanding heart." ${ }^{60}$ One American member of the 1944 chapter in Monterrey accused then-Mexico City director, Mrs. Arthur Constantine, of exhibiting "I-ism rather than Pan-Americanism." ${ }^{61}$ In short, American members in Mexico City were not good Pan Americans. While the issue of decision-making was resolved in 1944 with the formation of the Alliance of Pan American Round Tables, one could not predict how agents of Pan Americanism would understand their mission. ${ }^{62}$ By then, clubs throughout Latin America had formed-two in Mexico, one in Cuba, one in Honduras, one in Nicaragua, and one in Colombia. ${ }^{63}$

Criticism of Mexico City members was not unfair, but Griswold and others failed to perceive colony women as both products and benefactors of their privileged, exclusive positions. Early on, they used Pan Americanism to meet personal needs, focusing on self-study and choosing "Mexico" as their theme for 1932. ${ }^{64}$ While it seems ironic to choose to learn about the country in which they lived, the insulation of the American Colony and the fact that many colonists were part of a new wave of expatriates arriving in the early 1920s meant that they were indeed learning about their neighbors for the first time. Over the next few decades, they broadened their reach, entertaining men of import from Canada, Chile, and El Salvador, and organizing Pan American Days and luncheons for important visitors such as prominent American professors, Latin American diplomats, and Pan American Union officials. They took excursions together to nearby Cuernavaca, Actopan, and Tlaxcala where they enjoyed lectures by prominent men like the famous anthropologist Alfonso Caso. Before the 1940s, they did little civic work: they sat on the Board of Trustees of the Benjamin Franklin Library, which opened in 1944, and they organized a ball to raise money for a campaign to fight polio. They briefly offered free English courses, began a scholarship program for students, and held a student essay contest on Pan Americanism. ${ }^{65}$

If the historical record before 1944 suggests that Mexico City members interpreted PART and Pan Americanism more broadly as a vehicle for self-improvement and as a means for maintaining social ties in the American colony, this soon changed. In the 1950s, under the leadership of Ola Hendrix, the wife of the president of Chevrolet Mexico (both returned to Austin, Texas), they did outreach work more typical of Texas Tables. The women helped sponsor a yearly book contest, soliciting works by Mexicans; winning essays were published by the Ministry of Education (SEP). They worked with the Benjamin Franklin Library on a "from children to children" campaign to provide bookmobiles to rural communities by raising money and collecting books from private schools in Mexico and the United States. 
They held grand Pan American Day celebrations at members' homes with an average of 100 people in attendance. And, by the late 1950s, they helped select and fund scholarships for young Mexican women who studied at universities in the United States.

The founding of a PART table in Monterrey, Nuevo León further exemplifies a shift in attitude by the 1940s. In contrast to the Mexico City group, this club was led by an American expatriate from San Antonio, Mrs. Collin McCown de Garza, and thus took on a more ideal Pan American identity from the beginning. After fifteen years in Mexico, the Monterrey director began to think of herself as Mexican. She is renown in club history as Monterrey's quintessential "good neighbor." ${ }^{66}$ The Monterrey group equally represented both sides of the border: the table was half Mexican-born and half American-born. Meetings were held in both Spanish and English, and, by the late 1950s, all business was conducted in Spanish. As studies on Monterrey by the historian Alex Saragoza suggest, American women living in Monterrey were generally married to Mexican men or were there as wives of men who did business in this industrial capital of Mexico. Rather than live symbolically apart, the fluidity and transnationality of living in the north shaped what quite possibly might be a more inclusive form of Pan Americanism, especially compared to the Mexico City club. Time was also a factor in this shift. By the 1940s, the geo-political landscape changed and the American Colony in Mexico City changed with it. Many Americans returned to their homes in the United States during World War II. Those who stayed lived in Mexico amid a different climate. The United States and Mexico worked together as neighbors toward a common democratic cause. Pan American friendship became the official business of the U.S. State Department through the Office of the Coordinator for Inter-American Affairs which looked to groups like the PART as models for civic action.

By 1944, PART's leadership in Texas gave its transnational movements wings by establishing a separate entity under the Alliance of Pan American Round Tables. This gave Latin American clubs autonomy from the Texas directorate. Mexico's members, in particular, became the most active leaders in the broader Pan American movement that swept across the Americas in the post-World War Two era. Today, Mexico enjoys the largest membership in the Alliance with over eighty-six Tables.

\section{Conclusion}

The PART's supposed apolitical mission of building friendship and its normative activism fit with more widely accepted ideas about the place and role of women in politics, especially among receptive women in Latin America, many of whom were members of the professional class or the 
American expatriate community. The PART denied its characterization as just another woman's club, although it functioned a lot like one. Its history adds a caveat to scholarship on American clubwomen and women's volunteerism by exploring a group with both a national and international vision. Pioneering studies have explored "organized womanhood" in the nineteenth and early twentieth centuries as the place where "proper ladies flourished," voiced their independence and, thus, became early feminists (or proto-feminists), whether knowingly or not. ${ }^{67}$ Because the issue of suffrage did not appeal to the majority of middle-class women, clubs across the United States emerged by the late nineteenth century to address issues important to women, namely concerns of morality that society expected them to uphold, model, and spread. More recent studies on clubwomen's work show how women's club activism shaped broader movements like environmental conservation. ${ }^{68}$ Members of the PART, indeed, formed the backbone of civic Pan Americanism, becoming a model for other groups by the 1940s.

Although PART leaders denied their role as internationalists, PART members were little different than the women of WILPF who tried to export the U.S. suffragist movement to Latin America. PART members may have scorned feminist causes, but they were no less prescriptive or paternalistic than the women they deemed so radical. Just as widespread political participation is an ideal of American liberalism, so too is multilateralism a key goal of Pan Americanism. ${ }^{69}$ Friends stand with one another, and so would Latin America stand with the United States. Civic groups like the PART ultimately worked to build a peaceful hemisphere of good neighbors with shared values. They carried out this mission within the confines of gender norms. Griswold, especially, highlighted the connection between Pan Americanism and femininity. She took the time to lend a personal, female touch to the mission, sending flowers to ill leaders and communicating with wives of government officials. ${ }^{70}$ In this framework, the women of the PART played a role in forging a hemispheric community that became vital by World War Two and the Cold War. They set out to raise Pan Americans, a form of activism that allowed "typical" clubwomen to serve a higher foreign policy mission. As an extension of women's domestic work, rearing Pan Americans offered women an opportunity to improve self, community, nation, and hemisphere within the confines of acceptable gender roles.

\section{Notes}

I'd like to thank Loyola University Chicago for its support of this project over the past few years and especially Victor Macías González for first telling me about the PART at a conference in 2006. Thanks to Lisa Fine, Nicole Sanders, Suzanne 
Kaufman, and Michelle Nickerson who gave me feedback on this article in its many stages. Finally, I'd like to thank the anonymous readers and Jean Quataert at the Journal of Women's History for their valuable comments.

${ }^{1}$ Address of E.L. Reed, Esq., Chief of the Mexican Division, Department of State, delivered at the International Bridge, dedicating a marker erected April 14, 1935, in honor of the women of America. Pan American Round Tables of Texas Records, 1919-2007, MS 151, 23:1, Archives and Special Collections, University of Texas at San Antonio Library (hereafter PART-T Records).

2John Barrett, untitled essay. No date but written in early 1920s. John Barrett Papers, Library of Congress Manuscript Division (hereafter Barrett Papers), Box 104.

${ }^{3}$ Barrett, Address at NYU Commencement Ceremony, June 5, 1912. Barrett Papers, Box 114. He also published countless works on this concept: "Practical PanAmericanism" The North American Review 202, no. 718 (September 1915), 413-23; Practical Pan-Americanism (Washington, D.C.: The Pan American Union, 1915).

${ }^{4}$ Office of the Coordinator for Inter-American Affairs, "Some specific suggestions for Inter-American Programs," 2nd edition, 1943. Pamphlet found at the Columbus Memorial Library.

5 Lois Terry Marchbanks, The Pan American Round Table (N.p.: Avon Behren Press, 1983), 7.

${ }^{6}$ Ibid.

7Barrett, “Mexico: A Land of Potentiality,” 1917, Barrett Papers, Box 104.

${ }^{8}$ The founding dates of Texas Pan American Round Tables are as follows: San Antonio, 1916; Laredo, 1921; El Paso, 1921; Austin, 1922; Brownsville I, 1932; McAllen, 1934; Houston, 1940; Brownsville II, 1941; Fort Worth I, 1944; San Benito, 1948; Conroe, 1949; Dallas 1949; Alamo/San Juan/Pharr, 1949; Eagle Pass, 1953; Corpus Christi, 1955; Edinburg, 1958; Beeville, 1963; Fort Worth II, 1964; Del Rio, 1970; Odessa, 1977. A few other tables were founded outside of Texas: Las Cruces (1931) and Albuquerque (1945), New Mexico; San José (1951), Los Gatos-Saratoga (1960), and San Diego (1966), California. Today, the Alliance lists a total of twentyfour tables in Texas, two in Florida (Miami and Treasure Coast), one in Washington, D.C., one in Tulsa, Oklahoma, six in New Mexico, and three in California. How active these groups are varies.

${ }^{9}$ The same holds true for the handful of other early groups like the Pan American Society. Men of the 1912 Pan American Society worked in the fields of international business and law or were academics and retired diplomats. They thus had exposure to Latin America and its people in ways most Americans did not in the early twentieth century. It also makes sense that the Pan American Society had clubs in major commercial hubs such as New York and San Francisco with auxiliary members of industrial cities such as Portland, St. Louis, Chicago, and Philadelphia.

10Paige Meltzer, "“The Pulse and Conscience of America': The General Federation and Women's Citizenship, 1945-1960," Frontiers: A Journal of Women's Studies 30, no. 3 (2009), 52-76 and Meltzer, "Maternal Citizens: Gender and Women's Activism in the United States, 1946-1960" (PhD diss., Brown University, 2010). 
${ }^{11}$ Meltzer, "The Pulse and Conscience," 62-5.

${ }^{12}$ Letter from Griswold to WIPFL member Kathleen Jennison Lowrie on May 16, 1930 responding to her invitation. PART-T Records, MS 151, 8: 1 and Anonymous, "The Origin of the Pan American Round Table," n.d. Archives for Research on Women, PART-SA, RG no. 3: Box 1/Folder 1.

${ }^{13}$ See Meltzer's work.

${ }^{14}$ Letter dated November 27, 1940. PART-Texas Records, MS 151: Box $9 /$ Folder 1 of 5.

${ }^{15}$ Scholars have examined how artists, capitalists, tourists, dancers, and musicians mediate foreign relations and forward state agendas like the Good Neighbor Policy of the 1930s and the policy of Western coalition building through won "hearts and minds" during the Cold War. See Helen Delpar, The Enormous Vogue of Things Mexican: Cultural Relations between the United States and Mexico, 1920-1935 (Tuscaloosa, AL: University of Alabama Press, 1995); Christopher Endy, Cold War Holidays: American Tourism in France (Chapel Hill: University of North Carolina Press, 2004); Geoffrey C. Middlebrook, "The Bureau of Educational and Cultural Affairs and American Public Diplomacy during the Reagan Years: Purpose, Policy, Program, and Performance" (PhD diss., The University of Hawaii, 1995); Ben D. Mor, "Public Diplomacy in Grand Strategy," Foreign Policy Analysis 2 (2006), 157-76; Julio Moreno, Yankee Don't Go Home! Mexican Nationalism, American Business Culture, and the Shaping of Modern Mexico, 1920-1950 (Chapel Hill: University of North Carolina Press, 2003); Frank A. Ninkovich, The Diplomacy of Ideas: U.S. Foreign Policy and Cultural Relations, 1938-1950 (Cambridge: Cambridge University Press, 1981); Naima Prevots, Dance for Export: Cultural Diplomacy and the Cold War (Hanover, N.H.: University Press of New England, 1998); Emily S. Rosenberg, Spreading the American Dream: American Economic and Cultural Expansion, 1890-1945 (New York: Hill and Wang, 1982); Emily S. Rosenberg, Financial Missionaries to the World: The Politics and Culture of Dollar Diplomacy, 1900-1930 (Durham, N.C.: Duke University Press, 2003); Christine M. Skwiot, The Purposes of Paradise: U.S. Tourism and Empire in Cuba and Hawai'i (Philadelphia: University of Pennsylvania Press, 2012); Penny M. Von Eschen, Satchmo Blows Up the World: Jazz Ambassadors Play the Cold War (Cambridge, MA: Harvard University Press, 2004); and Gregg Wolper, "The Origins of Public Diplomacy: Woodrow Wilson, George Creel, and the Committee on Public Information" (PhD diss., University of Chicago, 1991).

${ }^{16}$ Elizabeth A. Cobbs, The Rich Neighbor Policy: Rockefeller and Kaiser in Brazil (New Haven: Yale University Press, 1992); Greg Grandin, Fordlandia: The Rise and Fall of Henry Ford's Forgotten Jungle City (New York: Picador, 2010); Thomas O'Brien, The Revolutionary Mission: American Enterprise in Latin America, 1900-1945 (Cambridge: Cambridge University Press, 1996). On Wilson and Roosevelt, see: Mark T. Gilderhus, Pan American Visions: Woodrow Wilson in the Western Hemisphere, 1913-1921 (Tucson: The University of Arizona Press, 1986); Fredrick B. Pike, FDR's Good Neighbor Policy: Sixty Years of Generally Gentle Chaos (Austin: University of Texas Press, 1995); and David Sheinin, ed., Beyond the Ideal: Pan Americanism in Inter-American Affairs (Westport, CT: Greenwood Press, 2000). 
${ }^{17}$ Megan Threlkeld, "The Pan American Conference of Women, 1922: Successful Strategists Turn to International Relations" Diplomatic History 31, no. 5 (November 2007), 801-28.

${ }^{18}$ Donna J. Guy, "The Pan American Child Congresses, 1916 to 1942: Pan Americanism, Child Reform, and the Welfare State in Latin America" Journal of Family History 23, no. 3 (July 1998), 272-91; Donna J. Guy, "The Politics of PanAmerican Cooperation: Maternalist Feminism and the Child Rights Movement, 1913-1960" Gender \& History 13, no. 3 (November 1998), 449-69; K. Lynn Stoner, "In Four Languages But with One Voice: Division and Solidarity within Pan American Feminism, 1922-1933," in Beyond the Ideal: Pan Americanism in Inter-American Affairs, Sheinin ed., 79-94.

${ }^{19}$ Joseph Smith, "The First Conference of American States (1889-1890) and the Early Pan American Policy of the United States," in Beyond the Ideal, 20.

${ }^{20}$ Territorial conflicts like the War of the Pacific and War of the Triple Alliance plagued South America by the second half of the nineteenth century.

${ }^{21}$ Smith, "The First Conference of American States," 20-3.

${ }^{22}$ Salvatore Prisco, III, John Barrett, Progressive Era Diplomat: A Study of a Commercial Expansionist, 1887-1920 (Tuscaloosa: University of Alabama, 1973) and Gilderhus, 16-20.

${ }^{23}$ Rowe worked for the U.S. government in several capacities dealing with law and arbitration in Puerto Rico and Panama while on faculty at Penn. See Ricardo D. Salvatore, "The Making of a Hemispheric Intellectual-Statesman: Leo S. Rowe in Argentina (1906-1919)," Journal of Transnational American Studies 2, no. 1 (2010), 1-36.

${ }^{24}$ David Barton Castle, "Leo Stanton Rowe and the Meaning of Pan Americanism," in Beyond the Ideal (Westport, CT, Greenwood Press, 2000), 33-44. See especially page 35 .

${ }^{25}$ Ibid.

${ }^{26}$ See J. Manuel Espinosa, Inter-American Beginnings of U.S. Cultural Diplomacy: 1936-1948 (Washington, D.C.: Department of State, 1976).

${ }^{27}$ Pan Americanism was fraught with problems, the least of which was the overall perception that the United States would "Westernize" Latin America. That said, exchanges between the United States and Latin America are not always negative or power-laden and can serve very real purposes of diplomacy. For a look into the controversial history of Pan Americanism, see John Edwin Fagg, Pan Americanism (Malabar, FL: Robert E. Krieger Publishing Co., 1982).

${ }^{28}$ Ibid., 8.

${ }^{29}$ PART-T Records, Box 47 / Folder 33 (1933).

${ }^{30}$ Table Talk, Vol. 111, no. 2 (November-December, 1944) 
${ }^{31}$ See 1944 McAllen Table Report given at the first PART-Alliance Convention held in Mexico City that same year, Box 1, 1928-46, and 1951 McAllen report in Box 2, 1947-51. Both located in the Alliance of the Pan American Round Table Records, Benson Latin American Collection, University of Texas Libraries, The University of Texas at Austin (hereafter Alliance Records). Collection is currently uncataloged.

${ }^{32}$ They first passed a PART resolution to take on this issue in 1933. See notes from the 1933 State Federation meeting in El Paso. Archives and Special Collections, PART-T, MS 151: Box 47 / Folder 22.Eventually, they watched their hopes turn into a Senate bill in 1941. See letters dated March 2 and April 7, 1941 in PART-T Records, Box 47 / Folder 2.

${ }^{33}$ See Silver City Report in Alliance Records, Box 2, 1947-51.

34"The Young Ambassador" was a 1942 radio series written by Miss Maria de Haro of Dallas. It centered on a young American boy, Jackie, living temporarily with his aunt and uncle in Mexico City while his parents travel throughout South America. Through his exploits with new friends Maria and Cho-Cho, Jackie learns about and begins to appreciate Mexico. Archives and Special Collections, PART-T, MS 151: Box 3/Folder 4.

${ }^{35}$ Transcripts can be found in Archives and Special Collections, PART-T, MS 151: Box 3/Folder 4. These programs were pretty formulaic and generic for the time. I have written extensively about other radio programs produced by Mexican and Texan tourism boosters that aired predominately in Texas. They are remarkably similar in theme to "The Young Ambassador." See Dina Berger, The Development and Promotion of Mexico's Tourism Industry: Pyramids by Day, Martinis by Night (New York: Palgrave Macmillan Press, 2006) and Dina Berger, "Goodwill Ambassadors on Holiday: Tourism, Public Diplomacy, and Mexico-U.S. Relations," in Dina Berger and Andrew Wood, eds. Holiday in Mexico: Essays on Tourism and Tourist Encounters (Durham: Duke University Press, 2010) 107-30.

${ }^{36}$ See various materials related to the art exhibit in Archives and Special Collections, PART-T, MS 151: Box 1/Folder 1. The figure of the final audience count may be higher than real numbers, but it is the number reported to the newspaper The San Antonio Light by Griswold on September 15, 1931. For details about the exhibit, see Delpar, 143-45.

${ }^{37}$ Alliance Records, Box 2, 1947-51.

${ }^{38}$ PART-T Records, MS 151, Box 8: $1 / 2$.

${ }^{39}$ Alliance Records, Box 2, 1947-51.

${ }^{40} \mathrm{All}$ correspondence related to the marker can be found in the Archives for Research on Women, PART-SA, RG \#3: Box 1/Folder 13.

${ }^{41}$ Current activities based on report given by Nidia Salamanca, Director of PART-Austin, at a PART luncheon at which I was an invited guest on October 1, 2007.

${ }^{42}$ Archives for Research on Women, PART-SA, RG \#3. Box 1/ 4 (n.d.); Alliance Records, Box 1, 1928-46. 
${ }^{43}$ Alliance Records, Box 2, 1947-51; Alliance Records, Box 3, 1951-55.

${ }^{44}$ Alliance Records, Box 1, 1928-46.

${ }^{45}$ Table Talk 1, no. 1 (October 16, 1942) in PART-T Records, MS 151, Box 2/14.

${ }^{46}$ Letter from Barbara McCluer to Director General of Alliance on September 27, 1953. Alliance Records, Box 3, 1951-55.

${ }^{47}$ Alliance Records, Box 3, 1951-55.

${ }^{48}$ Archives for Research on Women, PART-SA, RG \#3: Box 10/Folder 6.

${ }^{49}$ According to the Alliance of Pan American Round Tables (AMRP), there are currently 210 tables in 17 countries across the Americas with 7,210 members. http: / / www.alianzamrp.org/ eng.html (accessed on 22 June 2010).

${ }^{50}$ For example, see the chapter on PART-San Antonio in Adriana Ayala's "Negotiating Race Relations through Activism: Women Activists and Women's Organizations in San Antonio, Texas during the 1920s" (PhD diss., University of Texas at Austin, 2006), 129-63.

${ }^{51}$ William Schell Jr. has written extensively on the American Colony in Mexico City during the Porfiriato. See, Integral Outsiders: The American Colony in Mexico City, 1876-1911 (Wilmington, DE: Scholarly Resources Books, 2001). The most important studies on the American Colony after the Mexican Revolution are Ethelyn Clara Davis, "The American Colony in Mexico City" (PhD diss., University of Missouri, 1942); Kathy Denman, "La élite norteamericano en la Ciudad de México" (Mexico City: Centro de Investigaciones Superiores del INAH, 1980); and Birgit Nielsen, "The American Community in Mexico City during the Lázaro Cárdenas Administration: An American Island in Mexico City" (MA thesis, Simon Fraser University, 1977).

${ }^{52}$ Nielsen, "The American Community in Mexico City," iv and 81-4.

${ }^{53}$ Ethelyn Clara Davis, “The American Colony in Mexico City,” 226.

${ }^{54}$ Davis, "The American Colony in Mexico City," 226, and Nielsen, "The American Community in Mexico City," 82-3. Nielsen notes that marriages between Americans and Mexicans were discouraged; she finds that in 1938 only 13 percent married Mexicans. See Nielsen, 84.

${ }^{55}$ I have not been able to identify the person to which this statement refers. See 1930 PART Summary, Archives for Research on Women, PART-SA, RG \#3: Box 10 / Folder 6.

${ }^{56}$ Nielsen discusses how colony members resisted Mexicanization by frequent travel to and from the United States in addition to engagement in important religious, social, and educational institutions, 83-4 and 112.

${ }^{57}$ The University Club was founded by the American Colony in 1905 and the American Club in the 1890s by prominent American businessmen. Both were private clubs in downtown Mexico City. 
${ }^{58}$ This conflict first appears in the historical record in 1933. From the American women's perspective, see papers in the Archives for Research on Women, PART-SA, RG \#3: Box 5/Folder 8. From the Mexican group's perspective, see RG \#3: Box 1/ Folder 13.

${ }^{59}$ Letter dated November 27, 1940. Archives and Special Collections, PART-T, MS 151: Box 9/Folder 1 of 5.

${ }^{60}$ Letter dated December 19, 1940. Archives and Special Collections, PART-T, MS 151: Box 9/Folder 1 of 5.

${ }^{61}$ Letter between Texas directors dated October 6, 1944. Archives and Special Collections, PART-T, MS 151: Box 10/Folder 1 of 4.

${ }^{62}$ In a 2008 discussion with the Texas state director of PART, I was informed that Mexico City is not an active organization compared to the other Mexican clubs and that they generally have little contact with the women there.

${ }^{63}$ Most Latin American clubs were founded in the early 1950s, most likely as part of a broader endeavor to combat communism. While I will not include a discussion of the other Latin American clubs, it is interesting to note that many members sported titles of licenciadas (bachelor's degree) or doctoras (doctoral degree), meaning that they came from the educated, professional class.

64"1932 Report of the Work of the Pan-American Round Tables of Mexico City," Archives and Special Collections, PART-T, MS 151: Box 8/Folder 6.

${ }^{65}$ Reports on activities from Mexico City Table from 1941-44 in Archives and Special Collections, PART-T, MS 151: Box 44/Folder 6.

${ }^{66}$ I learned about the history of the Monterrey club in 2010 through extensive email communication with its then-director, Rosa Alicia Alanís de Sepúlveda. Rosa has graciously provided me with primary documents and most of the anecdotal information about the club. I have yet to explore the Monterrey table in depth but will return to the Alliance collection at the Benson in spring 2015.

${ }^{67}$ Karen J. Blair, The Clubwoman as Feminist: True Womanhood Redefined, 1868-1914 (New York: Holmes \& Meier Publishers, 1980), 1. For other pioneering studies on clubwomen in U.S. history, see Anne Meis Knupfer, Toward a Tenderer Humanity and a Nobler Womanhood: African American Women's Clubs in the Turn-ofthe-Century Chicago (New York: New York University Press, 1996), and Anne Firor Scott, Natural Allies: Women's Associations in American History (Urbana: University of Illinois Press, 1991). For a study that examines women's activism outside of a club context, see Megan Threlkeld's exceptional study on women internationalists entitled Pan American Women: U.S. Internationalists and Revolutionary Mexico (Philadelphia: University of Pennsylvania Press, 2014).

${ }^{68}$ See Shana Miriam Cohen, “American Garden Clubs and the Fight for Preservation, 1890-1980" (PhD diss., University of California, Berkeley, 2005); Priscilla G. Massmann, "A Neglected Partnership: The General Federation of Women's Clubs and the Conservation Movement" (PhD diss., University of Connecticut, 1997); and Jan Knight, "The Environmentalism of Edward Bok: The Ladies' Home Journal, the 
General Federation of Women's Clubs, and the Environment, 1901-1909," Journalism History 29, no. 4 (Winter 2004), 154-65.

${ }^{69}$ See Greg Grandin, “The Liberal Traditions in the Americas: Rights, Sovereignty, and the Origins of Liberal Multilateralism," American Historical Review 117, no. 1 (February 2012), 68-91.

${ }^{70}$ Griswold sent flowers to the White House in 1918 and to interim Mexican president General Adolfo de la Huerta in 1920. For Griswold's correspondence with officials, see Archives for Research on Women, PART-SA, RG \#3: Box 1/10. On many occasions, Griswold invited the wives of diplomatic corps and government officials in Mexico to luncheons and PART events. 